\title{
UM RIO CHAMADO TEMPO, UMA CASA CHAMADA TERRA: CONTRIBUIÇÃO DE MIA COUTO PARA OS DIREITOS FUNDAMENTAIS NA LITERATURA
}

\author{
VALÉRIA RIBAS DO NASCIMENTO' \\ FERNANDA GRAEBIN MENDONÇA²
}

\begin{abstract}
RESUMO: Este trabalho tem como base discutir a contribuição da obra Um rio chamado tempo, uma casa chamada terra, do escritor moçambicano Mia Couto, para o direito. $\mathrm{O}$ debate entra no sub-ramo "direito na literatura", no qual se evidenciam personagens e histórias envolvendo o direito. A narrativa gira em torno da viagem do jovem Mariano à ilha Luar-do-Chão, depois de anos longe de sua terra natal, para conduzir a celebração do funeral do seu suposto Avô Mariano. Quando chega à ilha, ele se vê impelido a reconstruir uma história que se fez sem sua participação. Marianinho precisa zelar pela memória da família e pelas tradições da ilha. A problemática reside em torno de como trabalhar os direitos fundamentais referentes à vida, morte, nacionalidade, igualdade e liberdade, em um contexto de tradições específicas como é Luar-do-Chão. Mia Couto utiliza metáforas e alegorias para fazer o leitor pensar, para além do texto, a sua própria vida, relacionando o "tempo" e a "casa" como eixos temáticos da leitura. A metodologia é a hermenêutica fenomenológica, pois o direito não deixa de sofrer as contingências histórico-culturais do universo em que se integra, desse modo, os conceitos jurídicos revelam-se como fenômenos históricos orientados à reflexão crítica.
\end{abstract}

Palavras-Chave: literatura; Mia Couto; tempo; casa, direitos fundamentais.

Pós-doutorado em Direito pela Pontifícia Universidade Católica do Rio Grande do Sul (PUCRS). Doutora em Direito pela Universidade do Vale do Rio dos Sinos (UNISINOS), com período de pesquisa na Universidade de Sevilha (US). Mestre em Direito Público pela Universidade de Santa Cruz do Sul (UNISC). Graduada em Direito pela Universidade Federal de Santa Maria (UFSM). Professora do Programa de Pós-Graduação em Direito da UFSM. Coordenadora do Núcleo de Direito Constitucional da UFSM. Santa Maria (RS), Brasil. CV Lattes: http://lattes.cnpq.br/6294253776126361. ORCID: https://orcid.org/o000-0002-8602-8148. E-mail: valribas@terra.com.br.

2 Mestre em Direito pela Universidade Federal de Santa Maria (UFSM). Graduada em Direito pela Universidade Federal de Santa Maria (UFSM). Bolsista CAPES. Santa Maria (RS), Brasil. CV Lattes: http://lattes.cnpq.br/7937877437014146. ORCID: https://orcid.org/o000-0003-1586-3477. E-mail: fernandagmendonca@gmail.com. 
O importante não é a casa onde moramos.

Mas onde, em nós, a casa mora.

(Avô Mariano - capítulo 4)

\section{À GUISA DE INTRODUÇÃO}

Existem relações óbvias entre literatura e direito, pois a primeira, muitas vezes, retrata os conflitos advindos das relações processuais e das violações a direitos, com suas consequentes cargas de justiça ou injustiça. Entretanto, o contrário não é uma prática comum, já que o sistema jurídico - via de regra - não se socorre da literatura para suas decisões. Destacamse alguns juristas e sociólogos que começaram a tentar preencher essa lacuna, como por exemplo, Ronald Dworkin (1999; 2000; 2002), Pierre Bourdieu (1996), François Ost (2004), bem como, no Brasil, já há um conjunto de pesquisadores trabalhando com o tema. Pode-se citar, a título de exemplificação, Germano Schwartz (2006), Valéria Ribas do Nascimento (2011), André Karam Trindade (2011), e este em parceria com Lenio Luiz Streck (2012), Ângela Araújo da Silveira Espíndola (2016), entre outros.

A temática deste trabalho gira em torno de uma das obras e Mia Couto, intitulada Um rio chamado tempo, uma casa chamada terra. Nesse sentido, ainda que brevemente, é mister destacar a importância da relação entre direito e literatura, devido à necessidade de se resgatar o senso de um tempo em que a justiça era poética ou quando os debates acadêmicos e sociais se desenvolviam em um ambiente de paixão, hoje abandonado pelo positivismo jurídico (Schwartz, 2006, p. 14-15). Como já é informação corrente, o movimento Law and Literature foi iniciado nos Estados Unidos da América nos anos setenta, aperfeiçoando-se na seguinte década, tendo como objetivo verificar na literatura pontos de contato que forneçam ao direito diferentes subsídios para entender o bem e o mal, o justo e o injusto, o legal e o ilegal, dentre outros dilemas humanos, facilmente encontrados nos diferentes tribunais nacionais e internacionais. Via de regra, existe uma divisão metodológica para se estudar esse movimento: o Direito na Literatura, o Direito como Literatura e o Direito da Literatura. Aqui, como o estudo partirá da representação do direito através de uma obra literária, será apresentada a primeira perspectiva. Ainda, destaca-se que se delimita a pesquisa em torno de determinados direitos fundamentais abordados na 
obra literária, como por exemplo, direito à vida ou à morte, à nacionalidade, à igualdade e à liberdade.

Assim, a problemática reside em apresentar algumas reflexões a partir da mencionada obra para se tentar entender como uma ficção africana pode influenciar a sociedade contemporânea, para além das alegorias e metáforas apresentadas no texto. Dessa forma, procura-se relacionar cada um dos personagens principais do texto com o contexto jurídico. Dentre os personagens principais, destaca-se: o jovem Mariano, o Avô Mariano, Abstinêncio, Fulano Malta, Ultímio, Mariavilhiosa, Dulcineusa, Miserinha e Admirança.

Salienta-se que não é objetivo do presente trabalho esgotar o assunto em torno do tema, mas sim traçar algumas perspectivas que possam lançar luz a um direito dogmático, positivo e muitas vezes ultrapassado, através do poder crítico da literatura. O método de abordagem adotado é o da hermenêutica fenomenológica, pois o direito, como é uma disciplina inserida dentro das ciências humanas e sociais, somente pode ser percebido se orientado para a reflexão crítica, logo precisa ser sensibilizado pelo entrelaçamento entre os fatos, normas e a própria literatura.

Segundo François Ost (2004), se por um lado o direito codifica a realidade, por outro a literatura libera os possíveis. Se o direito é o terreno da segurança, da certeza que é produzida pela pretensa completude da norma; a literatura é o terreno da surpresa, do inesperado. Se o direito produz pessoa, a literatura produz personagem e se desdobra no particular e no concreto, afastada do terreno da abstração normativa que caracteriza as prescrições jurídicas.

Para facilitar a compreensão do leitor acerca tanto da história trazida pela obra de Mia Couto quanto das problemáticas jurídicas que dela se extrai, o trabalho é dividido em dois capítulos: o primeiro apresenta um resumo da obra de Mia Couto, buscando ressaltar os pontos e passagens principais da história; enquanto o segundo capítulo, então, fará esse entrelaçamento de forma mais direta, ao apontar novamente passagens da história da obra, ao mesmo tempo em que encontra nela questões jurídicas pontuais, importantes e atuais. 


\section{UM RIO CHAMADO TEMPO, UMA CASA CHAMADA TERRA: BREVE RESUMO DA OBRA}

A obra ora analisada trata da viagem do jovem Mariano (também chamado de Marianinho) à ilha de Luar-do-Chão. Essa caminhada só aparentemente é apenas um retorno a sua terra natal, pois de forma oculta significa uma volta de Mariano às suas raízes na busca pelo descobrimento de sua própria história e no resgate do sentido da vida de vários personagens e da própria ilha.

Depois de longos anos longe da ilha, ele é um estrangeiro em sua casa e entre os de sua raça. Na cidade, adquiriu hábitos de branco, ou como falam no local, de um mulungo. No decorrer da narrativa, ele descobre que voltou à ilha não apenas para dirigir o cerimonial fúnebre de seu suposto Avô, mas para um renascimento que é tanto pessoal quanto familiar e comunitário.

Logo no início do romance, quando o estudante se prepara para retornar à ilha, os fragmentos de memória do tempo em que vivera com sua família já começam a se mostrar:

Os outros familiares eram muito diferentes. Meu pai, por
exemplo, tinha a alma à flor da pele. Já fora guerrilheiro,
revolucionário, oposto a injustiça colonial. Mesmo
internado na ilha, nos meandros do rio Madzimi, meu
velho Fulano Malta transpirava o coração em cada gesto.
Já meu tio Ultímio, o mais novo dos três, muito se dava a
exibir, alteado e sonoro, pelas ruas da capital. Não
frequentara mais a sua ilha natal, ocupado entre os
poderes e seus corredores. Nenhum dos irmãos se dava,
cada um em individual conformidade. O tio Abstinêncio
[...] sempre assim se apresentou: magro e engomado,
ocupado em traçar lembranças. Um certo dia, se exilou
dentro de casa. Acreditaram ser arremesso de humores,
coisa temporária. Mas era definitivo (Couto, 20o3, p. 16-
17).

O ressurgir das lembranças, a partir do sentimento de retorno a seu lugar de origem, acontece por meio da descrição de Marianinho sobre a diferença entre os familiares. Tais lembranças referem-se a episódios da história da família Malilane e a conflitos sociais e psicológicos que os personagens enfrentam em seu cotidiano. As agitações familiares têm como pano de fundo a situação de decadência, mesmo após a independência, resultado da troca de um mundo em que o sistema de valor não funciona mais em nome da tecnologia ou da modernidade dos costumes. Vale destacar outra citação: 
Me empoleiro no atrelado do tractor, vou circulando entre os caminhos estreitos de areia. Até há pouco a vila tinha apenas uma rua. Chamavam-lhe, por ironia, Rua do Meio. Agora, outros caminhos de areia solta se abriam, num emaranhado. Mas a vila é ainda demasiado rural, falta-lhe a geometria dos espaços arrumados (Couto, 2003, p. 27).

Como se pode perceber, o protagonista começa não só a se deparar com a falta de progresso na ilha, mas também a se posicionar como um sujeito esclarecido, que tem como referência de modernidade a cidade na qual se formou. A ilha, para ele, embora tenha passado por transformações, preserva raízes rurais, que não atraem seu gosto de homem citadino. Registra-se aqui que o personagem irá se modificando, conforme o decorrer da narrativa e o contato com as cartas misteriosas que recebe do Avô. Assim, o embate entre a tradição e a modernidade reforça um dos motivos da fragmentação da identidade de Marianinho, visto que o conjunto de valores mantidos em Luar-do-Chão é muito diferente daqueles apreendidos na cidade.

Os dias que antecedem o enterro do Avô Dito Mariano - o munumuzana, que significa o homem mais velho da família - são marcados por lembranças e revelações. Simultaneamente à condução do velório, Marianinho se vê impelido a reconstruir uma história que se fez basicamente - sem sua participação, pois foi muito cedo estudar na cidade. O protagonista se vê obrigado a zelar pela memória e tradição da ilha, devendo, por exemplo, decidir pela remoção ou não do telhado da Nyumbakaya - casa da família - durante o velório.

No decorrer da narrativa, na medida em que irá se refazendo a história familiar dos Malilanes - ou Marianos, na língua dos brancos -, Marianinho recebe uma séria de cartas anônimas que irão conduzi-lo na investigação da morte inacabada do Avô e de outros mistérios que envolvem toda a ilha. Cabe ao jovem perceber que cada habitante do lugar tem algo a lhe revelar, assim como deve resistir à velocidade do tempo para levar a termo o funeral do Avô no momento certo.

É importante ressaltar que Luar-do-Chão encontra-se em um estado de abandono, decadência e miséria. Nesse sentido, não se trata apenas de destroços materiais, mas do próprio tempo sendo reconstruído. Esse tempo mágico das tradições africanas. A missão de Marianinho é encontrar uma 
nova forma de salvar a terra, que também metaforicamente é sua casa, e levar adiante uma história que, além de pessoal e familiar, é também política e social.

\section{UM RIO CHAMADO TEMPO, UMA CASA CHAMADA TERRA E UM DIREITO CHAMADO "DIREITO NA LITERATURA": AS IMPLICAÇÕES JURÍDICAS DA OBRA}

A viagem do jovem Mariano a Luar-do-Chão para conduzir o cerimonial de enterro de seu suposto Avô é recheada de mistério, iniciando pelo próprio "defunto", o qual ainda não se sabe se está realmente morto, pois não são todos os sinais vitais que desapareceram. Veja-se,ipsis litteris, o texto da obra:

- E então, doutor?

- Então, o que?

O médico sacode a cabeça, sem expressão. Vezes sem conta já se tinha debruçado sobre o Avô, tomando o pulso, levantando a pálpebra, apalpado o peito. Uma vez mais se sujeitava ao retido interrogatório:

- Ele está morto, doutor?

- Clinicamente morto.

- Como clinicamente? Está morto ou não está?

- Eu já disse: ele está em estado cataléptico.

- Estado quê?

Amílcar ergue os olhos para o tecto, enquanto os dedos, nervosos, percorrer a borda do copo já vazio.

- Explica melhor; doutor; não estamos habituados a esses vocabulários. Diga uma coisa: ele respira ou o coração bate?

- Respira mas a um nível quase imperceptível. E o pulso está tão fraco que não o sentimos.

Silêncio enchendo um vazio tenso (Couto, 2013, p. 3536).

Mariano (protagonista - neto do "pseudomorto") recebe a missão de restaurar a normalidade da vida na ilha, por meio da compreensão dos dramas interiores de cada um de seus familiares, e percebe a necessidade de desvendar segredos antigos. Insere-se, também, assim um espaço de profundidade psicológica na caracterização dos personagens, símbolos de diversas formas de existência e lutas internas do próprio homem.

Nessa parte da obra, já é possível perceber uma questão jurídica bastante polêmica e atual, que é o surgimento de um ramo do direito, chamado "direito de morrer", pois a Mariano é dada a tarefa de escolher ou não enterrar o Avô Mariano naquele estado de "quase" morte. Esse novo ramo do direito está relacionado com a eutanásia em suas diversas formas e 
ao suicídio assistido ${ }^{3}$, haja vista a necessidade de compreensão das dificuldades enfrentadas pelo grande número de pacientes gravemente doentes que, diante de dores físicas e psíquicas, almejam a morte, e por outro lado, as limitações impostas pelo Estado ao afirmar o princípio da indisponibilidade da vida (Sá, 2005, p. 139).

Percebe-se que uma das grandes problemáticas desse texto de Mia Couto gira em torno da questão da vida e da morte, importantes direitos fundamentais tutelados pela quase maioria dos Estados Democráticos de Direitos contemporâneos. Ao final do texto, se questiona metaforicamente se, muitas vezes, "os 'vivos' estão vivos, ou quando falecem, ainda assim, insistem em 'viver'?". O problema do direito de morrer, assim como um dilema da obra do autor, também se mostra delicado no campo jurídico, uma vez que envolve questões morais e até mesmo religiosas, o que faz com que dificilmente haja consenso sobre o tema. A interface entre direito e literatura, aqui, mostra que a vida real (regida pelo direito) inspira a arte (literatura), estando esta atenta aos mais pequenos e complexos detalhes daquela.

Sobre os personagens principais do romance em questão, vale observar que o tio mais velho de Mariano, "Abstinêncio", como o nome evidencia, abstém-se do mundo da vida, minimizando todo o contato com o mundo externo, tomado por um mutismo que o afasta até mesmo de sua família. O terno negro e a gravata por ele utilizados demonstravam a escuridão em que vivia. Segundo Abstinêncio, “o mundo já não tem mais beleza" (Couto, 2003, p. 17). No decorrer da narrativa, cabe a Mariano resgatar, se é que é possível, o sentido da vida de toda a família e da própria ilha.

O tio Ultímio, terceiro dos três filhos, é o que menos percebe a relevância da terra, da família e das tradições, como elementos constituintes do homem, uma vez que, como "político" e burocrata, busca

\footnotetext{
Pode-se referir que eutanásia ativa é aquela provocada por ação de terceiro e a passiva, praticada pela omissão de alguém; a ortotanásia se perfaz com a abstenção ou limitação de tratamento fútil; a distanásia é sinônimo de obstinação terapêutica, ou melhor, os cuidadores do paciente prolongam ao máximo a vida humana; já a mistanásia seria a morte através da desproporção - fora ou antes da hora, por exemplo, por falta de atendimento. Por último, o suicídio assistido é consequência da própria ação do paciente com a ajuda de terceiros. Para aprofundar o assunto, consultar Maria de Fátima Freire de Sá (2005). Ainda, cita-se a obra de Luciana Dadalto (2013).
} 
agradar a todos para atingir seus interesses pessoais e procura ostentar riqueza para que as pessoas pensem que sua vida é maravilhosa. Em uma das passagens da obra é mencionado que "a política é a arte de mentir tão mal que só pode ser desmentida por outros políticos" (Couto, 2003, p. 28). Ultímio sempre espalhou enganos e parece ter lucrado, acumulando alianças e influências.

Com esse personagem é possível pensar a realidade atual, não apenas do Brasil, mas também de diversos países em que aparece a crise da (na) política, como uma das crises de Estado ${ }^{4}$. O modelo de democracia representativa inviabiliza a tomada de decisão por todos os interessados através das assembleias de cidadãos, como versão da antiga democracia ateniense, em face das dificuldades técnicas trazidas pelo tipo e conteúdo dos temas postos em discussão, o que transformou a política, muitas vezes, em refém das referências tecnológicas, das estatísticas, das probabilidades e das valorações macro e microeconômicas.

Ademais, a falta de tempo e a vida agitada deixam pouco espaço para o cidadão se ocupar do jogo político, o que conduz ao esvaziamento da política, ou seja, deixa-se de discutir questões essenciais ao povo para relacioná-la apenas como um estereótipo formal pelas ausências de alternativas reais de escolha. É o que José Luis Bolzan de Morais chama de "fantochização da democracia": dentro de um modelo de democracia representativa, percebe-se o enfraquecimento do espaço público da política, ocorrendo o desaparecimento de alternativas reais de escolha, posto que se estabelece um estereótipo de “desdiferenciação" de propostas, de "desidentificação" de candidatos etc, e conduzindo o cidadão a um processo de marasmo político (Morais, 2011, p. 71). As prerrogativas concedidas aos políticos, bem como a apatia dos cidadãos, é uma das evidências explícitas na obra de Mia Couto.

\footnotetext{
Para aprofundar as questões referentes às crises do Estado, recomenda-se a obra de José Luis Bolzan de Morais, intitulado "As crises do Estado e da Constituição e a transformação espaço-temporal dos direitos humanos”, no qual consta, primeiro, a crise conceitual, trabalhando-se com os elementos estruturais do Estado, posteriormente menciona-se a Crise estrutural, voltada para a finalidade do Estado de Bem-Estar Social. Já a crise constitucional relaciona-se com a própria efetividade da Lei Fundamental do Estado. Por outro lado, a crise funcional trabalha com a dificuldade que se tem hoje de delimitar a função de cada uma das atribuições de Estado, e, por fim, a crise política (e de representação) questiona a eficácia do atual modelo democrático (Bolzan de Morais, 2011, p. 25-74).
} 
Outro personagem da obra, Fulano Malta, é o pretenso pai de Mariano (ao final do romance é revelado que, na verdade, este é filho do Avô Mariano), protagonista da narrativa. O nome revela a melancolia em não se reconhecer, como ex-guerrilheiro, mesmo que os resultados da guerra permaneçam vivos em sua memória. O fato aconteceu quando Fulano Malta escutou falar que havia guerrilheiros lutando para acabar com o regime colonial perto de Luar-do-Chão. Ouvindo isso, lançou-se rio afora para se juntar aos independentistas. A família ficou sem saber dele durante anos, e, depois de já derrubado o governo colonial, Fulano Malta regressa fardado e todos o olhavam como herói de muitas glórias. Até que um dia aconteceu um ensaio para os festejos da independência, onde se esperava que os grandes homens que lutaram na guerra aparecessem. Ocorre que o pai de Mariano despiu a farda e se guardou em casa, afirmando que a independência que mais vale é aquela que está dentro de nós: "o que lhe apetecia celebrar era o vivermos por nosso mando e gosto" (COUTO, 2003, p. 72).

Nesse mesmo período do desfile, a mulher de Fulano Malta, Mariavilhosa, estava supostamente grávida, e aproveitando esse fato o pai de Mariano fez apenas uma declaração: "se é para aclamar bandeira eu escolho o redondo da sua barriga" (Couto, 2003, p. 73). Vale destacar as palavras do narrador quanto ao problema vivido pelo pai do protagonista:

\begin{abstract}
E nunca mais Fulano falou de políticas. O que dele a vida foi fazendo, gato sem sapato? Saí da Ilha, minha mãe faleceu. E ele mais se internou em seu amargor. Eu entendia esse sofrimento. Fulano Malta passara por muito. Em moço se sentira estranho em sua terra. Acreditara que a razão desse sofrimento era uma única e exclusiva: o colonialismo. Mas, depois veio a Independência e muito da sua despertença se manteve. E hoje comprovava: não era de um país que ele era excluído. Era estrangeiro não de uma nação, mas no mundo (Couto, 2003, p. 74).
\end{abstract}

Quando Mariano regressa para o enterro do suposto Avô, isso implicara em uma aprendizagem mútua, pois o pai, Fulano Malta, precisa aprender a ser pai e o filho necessitava reconhecer a pertinência dos atos que seu pai outrora cometera. Somente após esse resgate do passado é que Mariano entendeu Fulano Malta. 
Nessa passagem, é possível relacionar a situação vivida por Fulano Malta com nacionalidade e patriotismo. "Patriotismo" e "Nacionalismo" não são sinônimos, ainda que, dessa maneira, geralmente, sejam utilizados. Maurizio Viroli sustenta que os ideais do patriotismo têm sido empregados através dos séculos para fortalecer ou invocar o amor às instituições políticas e a determinadas formas de vida que defendem a liberdade comum para todas as pessoas, estando relacionados à questão republicana. Ao contrário, o nacionalismo desenvolveu-se no final do século XVIII, na Europa, para defender e reforçar a unidade cultural, linguística e étnica de um povos.

Além disso, Virole coloca:

[...] mientras que los enemigos del patriotismo republicano son la tiranía, el despotismo y la corrupción, los enemigos del nacionalismo son la contaminación cultural, la heterogeneidad, la impureza racial, y la desunión social, política e intelectual ${ }^{\circ}(1997$, p. 16).

Com o fim da Segunda Guerra Mundial, surgiram duas grandes potências mundiais, os Estados Unidos e a União Soviética, o que terminou por levar à reestruturação dos demais países, incluindo os Estados europeus e também os chamados países do Sul ou "em via de desenvolvimento". A crise histórica do Estado nacional se constitui na base da unificação da União Europeia. Isso fez surgir formas cada mais estreitas de cooperação política e econômica, o que levou a substituição da busca pela segurança individual de cada Estado à alvorada de uma nova época alicerçada na ideia de colaboração (Bobbio et al., 2002, p. 197-198).

Essa evolução, trabalhada na concepção de nacionalismo, possibilitou observar que, particularmente depois da Segunda Guerra Mundial, a

Segundo Pérez Luño, existem palavras que são utilizadas para designar realidades diversas ou momentos diversos da mesma realidade. Por isso, resulta conveniente não limitar a análise linguística, nem oferecer respostas provisórias, para não correr o risco de se dizer tantas coisas e não se dizer nada: "Se advierte así que el término pueblo puede evocar: el plethos o plenum, esto es, la totalidad de los ciudadanos; o bien, a los muchos, ho ypolloi; o bien, a la mayoría, hoy pleiones; e incluso a la masa, la acholos”. Assim, o autor chega a distinguir quatro sentidos diferentes para o mesmo termo: 1) Povo no sentido filosófico, entendido como totalidade orgânica; 2) Povo em sentido jurídico, como âmbito de validade do ordenamento jurídico estatal; 3) Povo concebido como categoria sociológica, referindo-se à coletividade de pessoas físicas de um Estado; 4) Povo como ideologia, ou seja, aquelas pessoas ou grupos que, por defenderem certas ideias majoritárias, qualificam-se como tal (Perez Luño, 2005, p. 197-198).

6 Tradução livre das autoras: "[...] enquanto os inimigos do patriotismo são a tirania, o despotismo e a corrupção, os inimigos do nacionalismo são a contaminação cultural, a heterogeneidade, a impureza racial e a desunião social, política e intelectual." 
complexidade trazida pela globalização interferiu diretamente em seu significado. Nessa linha de orientação e partindo da teoria de Immanuel Kant, sublinha-se a diferença entre a nacionalidade e o patriotismo. Aquela seria o vínculo formal que une determinado cidadão, comprometido em respeitar leis e costumes de determinado Estado. Já a pátria representa o âmbito de validade territorial do ordenamento jurídico estatal, relacionado aos ideais republicanos (Llano Alonso, 2002, p. 148).

Nesse mesmo contexto, Llano Alfonso afirma que Kant defende a dupla pátria: uma natural e outra legal: “[...] la existencia de la patria no es más que un hecho contingente en la historia de la humanidad y en [...] su continuo progreso hacia lo mejor". Ademais, ainda que não seja por ele afirmado expressamente, é possível verificar uma terceira acepção kantiana de pátria: "la pátria en sentido cosmopolita, es decir, ni más ni menos que el mundo"s (Llano Alonso, 2002, p. 148).

Vale destacar que o autor alemão, mesmo advogando pelo ideal cosmopolita, jamais abandonou o universalismo. Do ponto de vista antropológico, sempre contemplou a existência de diversos grupos culturais e, inclusive, de minorias nacionais, chegando a defender a preservação do idioma polonês nas províncias orientais da Prússia, mas isso não implicou que Kant apoiasse a divisão do gênero humano em compartimentos estanques, como sustentam os relativistas. Sua ideia é reconhecer a pluralidade dentro da universalidade, e isso é idealizado pelo humanismocosmopolita (Llano Alonso, 2002, p. 144 e 145).

A busca de Kant é por uma cidadania mundial como ideal moral que pode ser mantido através da perspectiva cosmopolita, ou seja, baseada em valores universais. Porém, cabe salientar que a crença na universalidade e na tutela do reconhecimento da igualdade entre todos os cidadãos pode ser percebida de forma moderada, como é a pretensão de quem defende um patriotismo cosmopolita (Fernández García, 2001, p. 110-111).

Aqui é importante lembrar que existem autores que possuem posições radicais em prol do cosmopolitismo, bem como outros que se colocam ao

Tradução livre das autoras: “[...] a existência da pátria não é mais que um fato contingente na história da humanidade e em [...] contínuo progresso para melhor."

8 Tradução livre das autoras: "a pátria no sentido cosmopolita, ou seja, nem mais nem menos que o mundo.” 
lado do patriotismo. Esse debate deu lugar, nos Estados Unidos, a um conjunto de réplicas referentes ao posicionamento de Marta C. Nussbaum, autora que afirma ser a identidade nacional uma categoria irrelevante (Nussbaum, 1999, p. 17). Logo, a filósofa americana reivindica uma cidadania mundial, baseada em um conceito de educação que denomina educação cosmopolita.

Consta-se que o patriotismo vincula-se a um sentimento voltado a questões públicas. Por isso, atualmente, costuma-se mencionar o "patriotismo cosmopolita" que ultrapasse a questão específica de Estado e que perceba a necessidade de proteção dos direitos humanos em todos os Estados, como uma questão primordial da humanidade.

Retornando a Um rio chamado tempo, uma casa chamada terra, destaca-se outra personagem, a velha Miserinha. Esta descreve o quadro sombrio inicial da viagem de Mariano à ilha. Todos metonimizados pela alegoria e vítimas, como o restante do país, da perda de identidade. Miserinha conversa com Mariano:

Eu não vejo cores. Não vejo nenhuma cor.

Doença que lhe pegou com a idade. Começou por deixar de ver o azul. Espreitava o céu, olhava o rio. Tudo pálido. Depois foi o verde, o mato, os capins - tudo autonecido, desverdeado. Aos poucos lhe foram escapando as demais cores.

- Já não vejo brancos nem pretos, tudo para mim são mulatos (Couto, 2003, p. 20).

O único resquício de cor visto por Miserinha é o lenço de seda multicolorido usado por ela e que representa a última memória das diferentes colorações do mundo, que contrastam, no entanto, com a roupa surrada e o rosto sombrio que só enxerga homens acinzentados, marcando a perda do desejo e da identidade. Miserinha era cunhada de Dulcineusa (esposa do Avô Mariano). Quando o marido dela morreu, vieram familiares que ela nunca tinha visto e levaram-lhe tudo, os bens, a terra e até a casa. Por isso, ela ressuscitou esse nome que lhe tinham dado na adolescência: Miserinha (Couto, 2003, p. 131).

Ao longo da viagem de volta a Luar-do-Chão, Mariano se depara, pois, com o regresso a casa para se ajustarem os detalhes do enterro do Avô. Aqui é importante abrir parênteses para destacar que casa é chamada de "Nyumba-Kaya" para satisfazer familiares do Norte e do Sul. "Nyumba" é a palavra para nomear "casa" nas línguas nortenhas. Nos idiomas do Sul, a 
casa é chamada de "Kaya”. Mariano percebe que a casa já está destelhada, para que o luto que ordena o céu se adentre por seus compartimentos e realize uma limpeza cósmica. Assim, a casa é regada diariamente como uma planta para que as águas não apenas a limpem, mas também a fertilizem (Couto, 2003, p. 28 e 29).

Quem cuida dos preparativos para o enterro é a Avó Dulcineusa, doce no nome para compensar a amargura da perda de parte da mão e dos dedos carcomidos, queimados, pela acidez do caju colhido ao longo da vida. Em momentos que alternam delírio e lucidez, Dulcineusa revela conflitos do homem diante da confluência de valores sociais, culturais e religiosos que lhe foram impostos ao longo da vida. Ela tinha uma irmã, Admirança, que era uma das personagens que aguardava a chegada do protagonista Mariano, ao retornar para o funeral do Avô, e que escondia segredos revelados ao final da obra, como, por exemplo, ser a verdadeira mãe de Marianinho (na verdade, ela tinha um relacionamento amoroso extraconjugal - com o Avô Mariano).

Mia Couto escreve que "todos os dias a Avó regava a casa como se faz a uma planta. Tudo requer ser aguado, dizia ela. A casa, a estrada, a árvore. E até o rio deve ser regado" (Couto, 2003, p. 31). Ressaltam-se a metáfora e as tradições africanas evidenciadas na necessidade de acolhimento e identificação entre as coisas e as pessoas.

Ao longo da narrativa, igualmente, a vida de Mariano é permeada por conflitos, dúvidas, surpresas e descobertas relacionadas primeiramente ao funeral, mas que acabam por demonstrar novos momentos para o protagonista e sua terra. Lançando mão da alegoria e da fantasia, o "Avô" Mariano (nome que foi passado ao neto) comunica-se com Marianinho por meio de cartas; por óbvio que estas não podem ser escritas por ele, já que se encontra em estado de catalepsia. As cartas aparecem misteriosamente ao pé do neto para lhe servir de diretriz sobre cada passo a ser dado na condução da finalização do funeral e, posterior, liderança da família.

O professor e doutor em letras Adelto Gonçalves afirma que o retorno de Marianinho à ilha para encontrar uma forma de salvar aquela terra, que também é sua casa, possui a intenção de demonstrar a necessidade de reconstruir um mundo novo, sem abandonar as tradições. Essa seria, também, a ideia de uma parábola da África pós-colonial que precisa juntar 
seus destroços para seguir adiante e não ficar irremediavelmente para trás na história dos Estados (Gonçalves, 2015).

É importante salientar a relação estabelecida entre a casa e o tempo, sublinhada pelo próprio título da obra, que permeia todos os aspectos da obra em todos os seus espaços e personagens. Insta observar uma das cartas do Avô Mariano a Marianinho:

Mariano, esta é sua urgente tarefa: não deixe que completem o enterro. Se terminar a cerimônia você não receberá as revelações. Sem essas revelações você não cumprirá a sua missão de apaziguar espíritos com anjos, Deus com os deuses. Estas cartas são o modo de lhe ensinar o que você deve saber. Neste caso, não posso usar os métodos da tradição. Você já está longe dos Malilanes e seus xicuembos. A escrita é ponte entre os nossos e os seus espíritos. Uma primeira ponte entre os Malilanes e os Marianos.

Alguns destes parentes vão querer abreviar este momento. Vão impor seus andamentos sobre o nosso tempo. Não deixe que isso aconteça. Não deixe. A sua tarefa é repor as vidas, direitar os destinos desta nossa gente. Cada um tem seus segredos, seus conflitos. Lhe deixarei conselho para guiar as condutas dos seus familiares. Não será só nas cartas. Lhe visitarei nos sonhos, também. Para você conhecer os dentros de seus parentes. E todos, aqui, são seus parentes. Ou pelo menos equiparentes. Seu pai, com suas amarguras, seu sonho coxeado. Abstinêncio com seus medos, tão amarrado a seus fantasmas. Ultímio que não sabe de onde vem e só respeita os grandes. Sua tia Admirança que é alegre só por mentira. Dulcineusa com seus delírios, coitada. Mas, lhe peço, comece por Miserinha. Vá procurar Miserinha. Traga essa mulher para Nyumba-Kaya. Estas paredes estão amarelecendo de saudade dessa mulher. Ela deve repertencer-nos. É nossa família. E a família não é coisa que exista em porções. Ou é toda ou não é nada (Couto, 2003, p. 125-126, grifamos).

Destaca-se como Mia Couto tenta resgatar o tempo através da vida e memória dos personagens, bem como pretende preservar a importância da família referindo a necessidade da busca por Miserinha e a urgência de levá-la para casa, que metaforicamente une todos os personagens, apesar da passagem do tempo.

É relevante registrar que há uma ruptura com a linearidade do texto, no uso da prosa poética e da apropriação da construção do fantástico dentro da realidade de seus personagens e da vida do próprio leitor. $O$ trabalho não deixa de ser "artesanal" através de seu léxico e registro de compromisso com a representação estética do mundo. Igualmente, o uso explícito de 
criações neológicas ultrapassa o registro de que seria uma linguagem regional para abarcar a exposição a um universo contraditório presente nas culturas contemporâneas (Gonçalves, 2015).

Segundo Adelto Gonçalves, o tempo e a casa selam uma união conjugal dentro do romance: "O tempo, em seu caráter masculino, representa os homens da história. Sofre um processo de desmoronamento (particular à casa) para refletir toda desconstrução dos homens desta família” (Gonçalves, 2015). Revela não apenas dependências emocionais, mas também ambições volúveis, desenganos cercados pela guerra do país e pela necessidade de paz, tanto interna como externa.

Aqui é possível abrir outro parêntese para relacionar o direito na literatura com toda uma construção jurídica que, atualmente, tem sido feita por vários doutrinadores ${ }^{9}$ em torno da defesa da paz mundial e da tutela dos direitos humanos e fundamentais. A defesa do princípio da dignidade humana tanto em âmbito interno como internacional é um dos paradigmas dos Estados Democráticos contemporâneos.

Retornando ao romance de Mia Couto, percebe-se que a casa, simbolizando o feminino, pode representar tanto os personagens femininos, pois é habitada habitualmente por mulheres, mas também é notável a altivez de ter sido erguida e mantida sólida, mesmo com o passar dos anos (Gonçalves, 2015). A morte do Avô Mariano, patriarca dos Malilanes, "é a morte da 'casa pai' e o nascimento da 'casa mãe', responsável pelo abrigo das peças que compõe a identidade de Marianinho mediada pela tradição e pela modernidade de seus valores" (Gonçalves, 2015).

Já na parte final do romance é feita uma revelação: o Avô Mariano que havia morrido não era "Avô" de Marianinho, mas sim seu pai. Foi um segredo de família mantido por um longo período. Na verdade, Marianinho era filho de Admirança, que mantinha escondida relação amorosa com o marido de sua irmã Dulcineusa. Aqui é revelada toda a complexidade das relações humanas, as quais, por consequência, fazem com que sejam igualmente complexas as relações e as questões jurídicas.

9 Em âmbito nacional, apenas a título de exemplificação, é possível citar Antonio Augusto Cançado Trindade (2015), Fábio Konder Comparato (2008), Flávia Piovesan (2006), Valéria Ribas do Nascimento (2010), etc., e, em âmbito internacional, Antonio Enrique Pérez Luño (2005), Peter Häberle (2000), Pablo Lucas Verdú (1998) etc. 
Sendo assim, através de metáforas e alegorias, Mia Conto faz o leitor pensar o direito na vida e da vida, para além desta e de outras vidas. Finaliza-se com um trecho da última carta do "Avô" Mariano: "Você meu neto, cumpriu o ciclo das visitas. E visitou casa, terra, homem, rio: o mesmo ser, só diferindo em nome. Há um rio que nasce dentro de nós, corre por dentro da casa e deságua não no mar, mas na terra. Esse rio uns chamam de vida" (Couto, 2013, p. 258).

\section{CONCLUSÃO}

O nó górdio dessa pesquisa reside em como perceber os direitos fundamentais na literatura através do romance Um rio chamado tempo, uma casa chamada terra, do moçambicano Mia Couto. Apenas para recordar, vale lembrar que o direito na literatura é o ramo da disciplina direito e literatura que estuda as formas sob as quais o direito é representado na literatura. Cada forma de tratamento poderá interessar a determinado campo jurídico. Neste trabalho, particularmente, foram destacados determinados direitos fundamentais levantados pelo autor da obra.

No texto ora em discussão, procurou-se evidenciar os personagens principais da narrativa em que era possível se fazer uma relação com as questões jurídicas. Dentre os principais temas abordados, tratou-se de um novo ramo no direito chamado de "direito de morrer", que trata principalmente da eutanásia e do suicídio assistido. Esse debate envolvendo os direitos fundamentais em torno da vida e da morte é assunto recorrente em toda obra. Vale lembrar o início da narrativa de Mia Couto: “A morte é como o umbigo: o quanto nela existe é a sua cicatriz, a lembrança de uma anterior existência” (Couto, 2003, p. 15). A obra do autor moçambicano já inicia com a suposta morte do Avô Mariano, pois o mesmo se encontra em estado de catalepsia, mantendo alguns sinais vitais, o que leva a família a questionar sobre a efetivação da finalização do funeral.

Para levar adiante o funeral do Avô Mariano, a família irá buscar na cidade seu "neto" Marianinho para comandar a celebração fúnebre. No entanto, a busca pelo neto tem vários sentidos, indo muito além de uma simples cerimônia. Mariano (neto) possui a missão de (re)descobrir sua própria história e devolver o sentido da vida aos parentes e à própria ilha 
Luar-do-Chão, onde tudo se desenvolve. O jovem irá descobrir que, na verdade, é filho e não neto do Avô Mariano.

Igualmente, vale registrar o importante trecho da narrativa em que Fulano Malta (que, inicialmente, era o pai do jovem Mariano) vai lutar pela independência e para acabar com o regime colonial. Aqui se evidencia a noção de patriotismo e nacionalismo, assuntos recorrentes no direito. Ocorre que Fulano Malta se decepciona completamente com a causa pública e política, iniciando um processo de afastamento dos membros da cidade e de sua própria família. Assim, foi possível trabalhar-se com algumas questões jurídicas envolvendo a crise política e democrática que assola muitos Estados contemporâneos.

Ademais, foram trabalhadas outras questões envolvendo temas críticos da área jurídica no decorrer do artigo. Entretanto, convém notar o tema central da obra de Mia Couto, lembrado na epígrafe desse artigo: "O importante não é a casa onde moramos. Mas onde, em nós, a casa mora”. Realmente, a "casa" relacionada metaforicamente com a família, amigos e lembranças do passado, identidade e cultura irá sempre permanecer junto às pessoas, onde quer que elas se encontrem, no tempo e no espaço.

\section{REFERÊNCIAS}

BOBBIO, Norberto; MATTEUCCI, Nicola; PASQUINO, Gianfranco. Dicionário de política, 1. Trad. de Carmen C. Varriale, Gaetano Lo Mônaco, João Ferreira, Luís Guerreiro Pinto Caçais e Renzo Dini. 12. ed. Brasília: Universidade de Brasília, 2002.

BOURDIEU, Pierre. As regras da arte. São Paulo: Companhia das Letras, 1996.

COMPARATO, Fábio Konder. A afirmação histórica dos direitos humanos. 6. ed. São Paulo: Saraiva, 2008.

COUTO, Mia. Um rio chamado tempo, uma casa chamada terra. São Paulo: Companhia das Letras, 2003.

DADALTO, Luciana. Testamento vital. Rio de Janeiro: Lumen Juris, 2013.

DWORKIN, Ronald. Levando os direitos a sério. São Paulo: Martins Fontes, 2002.

DWORKIN, Ronald. O império do direito. São Paulo: Martins Fontes, 1999.

DWORKIN, Ronald. Uma questão de princípio. São Paulo: Martins Fontes, 2000.

FERNÁNDEZ GARCIA, Eusebio. Dignidad Humana y ciudadania cosmopolita. Madrid: Dykinson, 2001. 
GONÇALVES, Adelto. Um rio chamado tempo, uma casa chamada terra. Passeiweb.

Disponível em:<http://www.passeiweb.com/estudos/livros/um rio chamado tempo uma casa chamada terra>. Acesso em: 3 abr. 2017.

HÄBERLE, Peter. Teoria de la Constitución como ciencia de la cultura. Trad. de Emilio Mikunda. Madrid: Editorial Tecnos, 2000.

LLANO AFONSO, Fernando H. El humanismo cosmopolita de Immanuel Kant. Madrid: Dykinson, 2002.

MORAIS, José Luis Bolzan de. As crises do Estado e da Constituição e a transformação espaço-temporal dos direitos humanos. Porto Alegre: Livraria do Advogado, 2011.

NASCIMENTO, Valéria Ribas do. "As viagens de Gulliver”, do século XVIII ao XXI: minúsculas ou gigantes orientações sobre o direito e a paz. In: XX Congresso Nacional do CONPEDI/UFES. Anais do... Belo Horizonte, 2011, p. 6353-6370. Disponível em: <http://www.conpedi.org.br/manaus/arquivos/anais/XXencontro/Integra .pdf>. Acesso em: 3 abr. 2017.

NASCIMENTO, Valéria Ribas do. O tempo das reconfigurações do constitucionalismo: os desafios para uma cultura cosmopolita. São Paulo: LTr, 2010.

NUSSBAUM, Martha. Patriotismo y cosmopolitismo. In: NUSSBAUM, Martha C.; COHEN, Joshua. Los límites del patriotismo: identidad, pertenencia y ciudadanía mundial. Trad. de Carme Castells. Barcelona: Paidós, 1999.

OST, François. Contar a lei. São Leopoldo: Unisinos, 2004.

PÉREZ LUÑO, Antonio Enrique. Derechos humanos, estado de derecho y constitución.9. ed. Madrid: Editorial Tecnos, 2005.

PIOVESAN, Flávia. Direitos humanos e o direito constitucional internacional.7. ed. rev. e ampl. São Paulo: Saraiva, 2006.

SÁ, Maria de Fátima Freire de. Direito de morrer: eutanásia, suicídio assistido. Belo Horizonte: Del Rey, 2005.

SCHWARTZ, Germano. A Constituição, a literatura e o direito. Porto Alegre: Livraria do Advogado, 2006.

STRECK, Lenio Luiz; TRINDADE, André Karam (Org.) Direito e literatura: da realidade da ficção à ficção da realidade. São Paulo: Atlas: 2012.

TRINDADE, André Karam. Kafka e os paradoxos do direito: da ficção à realidade. Revista Diálogos do Direito, v. 2, n. 2, 2012. Disponível em: $<$ http://ojs.cesuca.edu.br/index.php/dialogosdodireito/article/view/63/76 >. Acesso em:3 abr. 2017.

TRINDADE, Antonio Augusto Cançado. Os tribunais internacionais contemporâneos e a busca da realização do ideal de justiça internacional. Revista da Faculdade de Direito - UFMG, n. 57, 2010. Disponível em: <http://www.direito.ufmg.br/revista/index.php/revista/article/download/

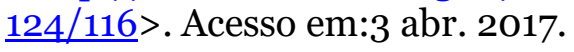


VERDÚ, Pablo Lucas. Teoría de la Constitución como ciencia cultural.2. ed. Madrid: Dykinson, 1998.

VIROLI, Maurizio. Por amor a la patria: un ensayo sobre el patriotismo y el nacionalismo. Trad. de Patrick Alfada. Madrid: Acento, 1997.

Idioma original: Português

Recibido: 05/04/17

Aceptado: 02/11/17 